\title{
THE ROLE OF IN-SERVICE TEACHER IN SUPERVISING PRE-SERVICE TEACHERS DURING TEACHING PRACTICUM PROGRAM
}

\author{
Diah Latifah \\ Department of Music Education, Indonesia University of Education \\ $\bowtie$ Jl Dr. Setiabudhi no 229 Bandung, Indonesia \\ E-mail: diah-singer@bdg.centrin.net.id
}

Received: September 13, 2014. Revised: November 5, 2014. Accepted: November 12, 2014

\begin{abstract}
This study analyzes the role of in-service teacher in supervising the pre-service teachers during the Teaching Practicum Program and in building the pre-service teachers' character to be competent music teachers in the future. This study implements narrative inquiry as the method of research. Narrative inquiry method explains the variety of cases during the process of supervision by the in-service teacher. In addition, the research was held in Pasundan 8 Senior High School Bandung and was analyzed further by using qualitative methods with interactive analysis as it is formulated in the research question of this study. Results show that the supervision by an inservice teacher has been successfully enhanced the ability of pre-service teachers in teaching art and culture, particularly music lesson. The competence of pre-service teachers can be achieved by giving them examples, model, and music experience from in-service of the pre-service teachers.
\end{abstract}

Keywords: in-service teachers' supervision; the competence of pre-service teachers in teaching music lesson

How to Cite: Latifah, D. (2014). The Role of In-Service Teacher in Supervising Pre-Service Teachers during Teaching Practicum Program. Harmonia: Journal of Arts Research and Education, 14(2), 88-96. doi:http://dx.doi.org/10.15294/ harmonia.v14i2.3290

\section{INTRODUCTION}

In-service teacher in Teaching Practicum Program has a role to prepare and supervise his participants to become music teachers. In-service teacher in Teaching Practicum Program specifically has a responsibility to give a real school teaching and learning experience to every pre-service teacher who attend the program. Training and guidance are usually given by compiling lesson plan, analyzing syllabus, and implementing learning components in the practice of classroom learning in the actual music classrooms. Participants of Teaching Practicum Program or the preservice music teachers are prepared to be professional teachers who are completely understanding the learning environment theoretically and practically. According to Puspitasari (2013, p. 33), in-service teacher who has a role as supervisor in Teaching Practicum Program, has a responsibility to guide the pre-service teachers (participants of the Teaching Practicum Program) to create a lesson plan as one of classroom teaching administration. The lesson plan which is made by pre-service teachers has a slight difference format with the actual lesson plan used at school. So far, pre-service teachers seem to not have any difficulties since the in-service teacher (the supervisor) has given them a set of lesson plan format examples. Subsequently, the 
pre-service teachers only need to adjust their lesson plan to the fixed format which is written in the provided example.

Frequently, the empirical facts regarding to the actual teaching are considerably different to the initial learning which has been firstly has given in the teaching education program at the university level. In its relation to clinical supervision, Puspitasari also argues that clinical supervision is a form of professional assistance that is based on the needs of pre-service teachers (student teachers), and derived from a systematical observation and analysis regarding the actual behavior of preservice teachers in the classroom. Parwoto $(1988$, p. 84$)$ states that this stage requires the pre-service teachers to practice their teaching and non-teaching skills integratedly and intact in the actual teaching situation under an intensive supervision from lecturers and in-service teachers.

The Teaching Practicum Program is an activity which aims to prepare pre-service teachers through an actual classroom teaching practice at schools. This program is located in schools or other institutions which provide teaching learning program for pre-service teachers. Hamalik (2005, p. 172) argues that Teaching Practicum Program is a series of activity that is programmed for students or student teachers comprises learning to teach or learning outside the teaching activity itself. This activity is an opportunity to develop professional competencies required by the work field of teachers or other educational personnel. Further, this activity is aiming to form the personality of pre-service teachers and to equip them with a set of knowledge, skills, values, attitudes, as well as a behavioral pattern. In addition to this are the competent and appropriate use of those aspects in the implementation of teaching and learning inside and outside schools.

Widiastuti (2013, p. 3) claims that Teaching Practicum Program is actually one of the essential curricular components which need integration between material comprehension and practice. Besides, the Teaching Practicum Program is one of intracurricular academic activity which comprises guided, focused, and integrated teaching practice and other educational duties to fulfill the requirement of the establishment of professionals in the field of education.

Supervision under the assistance of in-service teacher is a kind of supervision which is aiming to prepare pre-service teachers to become competent teachers. In other words, supervision purposes to provide teaching competency training to the pre-service teachers. Based on Shalaway (2005, p. 9),"teaching in today's classrooms calls for reflective professionals set apart by special knowledge and skills". It means, for teachers, teaching is not a kind of competence which can be possessed easily. It is more of an arrangement of special capabilities that shapes teachers become professionals. Here, the teaching competencies are given by in-service teachers through the process of music classroom teaching in the school environment to the pre-service teachers as the participants of the teaching practicum program.

The Teaching Practicum Program is a medium of giving teaching learning skills and knowledge training to pre-service teachers in order to form them becomes professionals. Soewito (2013, p. 6) argues that Teaching Practicum Program and Community Service Program (Kuliah Kerja Nyata) is integrated aiming to develop the competencies of university students to become pre-service teachers or other educational professionals, in particular. Programs which are developed in the implementation of Teaching Practicum are focused on school communities, clubs, or institutions. School communities comprise school internal community (teachers, staffs, and school committee) as well as societies around the school environment.

Besides the aspects described above, the changing of competencies which needs to be comprehended by students are the balance between hard skill and soft skill competencies. Curriculum development team (2013) states that there is an increase and balance between soft skills and hard 
skills in Senior High School comprise the competencies of attitudes, skills, and knowledge. Specifically, in Indonesian curriculum, the music lesson is derived from competencies. In the other words, the lesson has to be in accordance with the competencies. A study by Widarto (2012, p. 20) states that the hard skills and soft skills, learning strategy need to be implemented in order to prepare skilled employees. If the education is given at school, the active learning strategy will be relevant to be implemented.

This study is going to explain that inservice teachers should have the competencies to guide the participants of teaching practicum (pre-service teacher) in order to implement the balance of hard skill and soft skill through music learning for students. An example of regarding to the previous explanation is the ability to lead a small discussion in 'cooperative learning' learning model. Zaher and Nasir (2010) conduct a study about the importance of cooperative learning approach. Based on them, learning by this method is more effective rather than other traditional learning. This learning is considerably important to give an opportunity to the students to have more experiences in learning. Here, the role of in-service teacher is considered to be essential to help teachers in giving an active learning experience rather than the passive one.

Active learning experiences is considerably essential to students, Therefore, a pre-service teacher need to be aware and understand the principles of active learning, such as: action learning or what is known in music lesson as learning by experiencing music. Leonarda (2010, p. 121) states that the importance of learning using action learning is the opportunity to give students a space to develop their managerial and collaborative experiences.

As it has been explained previously, the theory of teaching and learning delivered in Teaching Education is frequently different with the empirical facts happened in the field. It is believed that this problem can be solved through the supervision by in-service teachers as the people who are in charge and have a considerable number of experiences in the actual music classrooms. This study is conducted to find out whether in-service teachers are having the competencies to mediate the difficulties to teach that might be faced by pre-service teachers and the need to implement the Indonesian newest 2013 curriculum which emphasizes the balance between hard skill and soft skill. Therefore, the research question in this study is "Is the in-service teacher supervision able to make the pre-service teachers to become competent music teachers?". From the research question, this study is aimed to analyze the function of in-service teacher supervision towards the pre-service teachers' readiness to become competent music teachers.

\section{METHOD}

This research implements narrative inquiry as the method of study. Narrative inquiry method explains a variety of cases and activities which happen during the supervision between the in-service to the pre-service music teachers.

\section{Design and Assumption of the Study}

Based on the research question stated above, the design of the study is illustrated in the following figure (see figure 1). From the presented chart, it is assumed that inservice teacher has several significant roles towards competencies in creating lesson plans, carrying out the learning process of a music lesson, and implementing both hard skill and soft skill to the pre-service teachers.

The data will be analyzed by (1) finding out the functions of in-service teacher's supervision regarding to the process of creating lesson plans for the preservice teachers, (2) finding out the functions of in-service teacher's supervision regarding to the implementation of learning process for the pre-service teachers, and (3) finding out the functions of in-service teacher's supervision regarding to the implementation of the balance between 


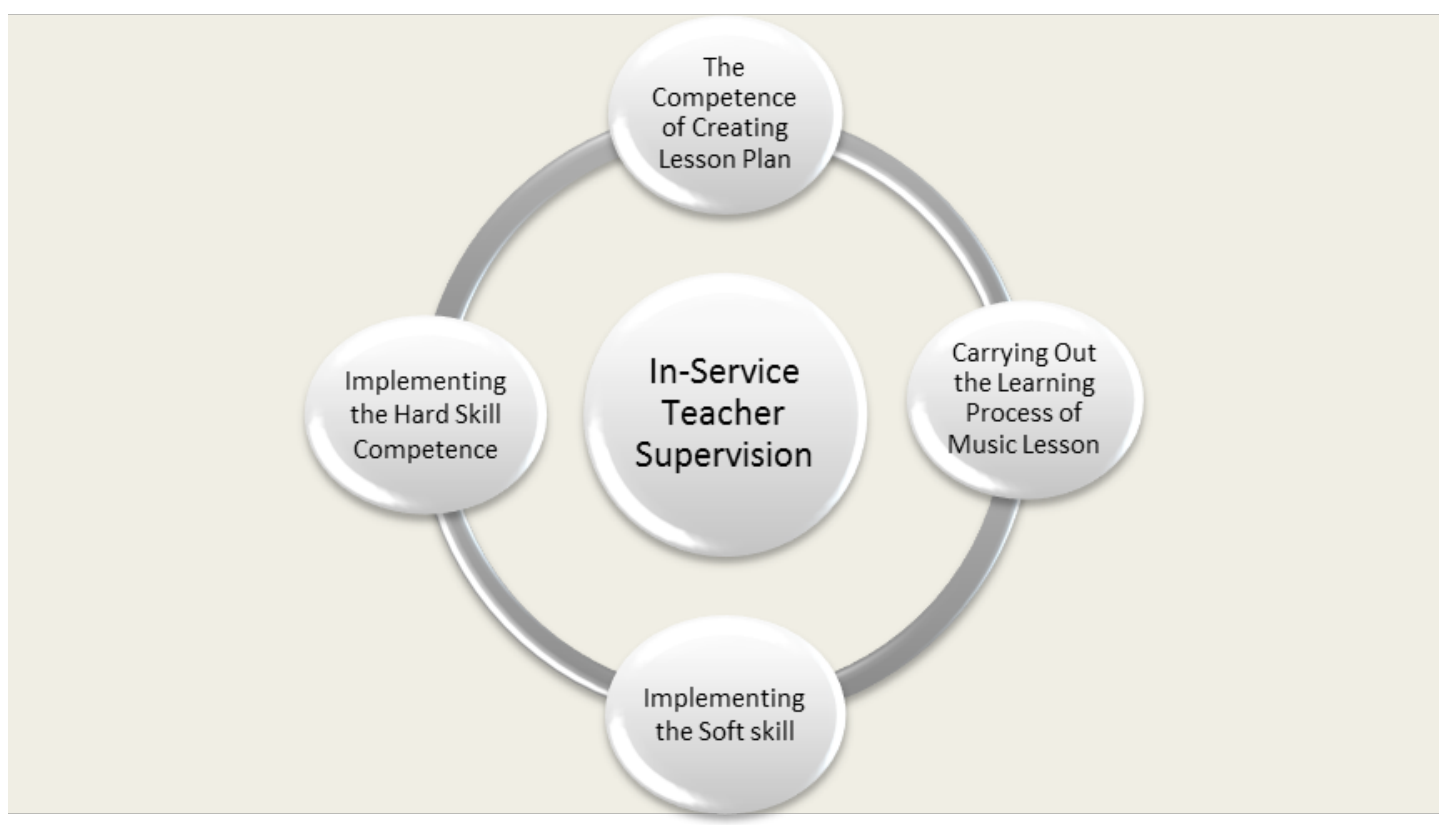

Figure 1. Chart of the Study Design (Latifah, 2014)

hard skill and soft skill.

\section{Data of the Study}

Data of the study which is going to be analyzed in this study are (1) the functions of in-service teacher supervision for the pre-service teachers, (2) the functions of in-service teacher supervision regarding to the implementation of the learning process for the pre-service teachers, (3) the functions of in-service teacher supervision regarding to the implementation of the balance between hard skill and soft skill for the pre-service teachers.

The study will be started by an initial observation to understand the school environment and examine the preparation of the in-service teachers before supervising the pre-service teachers. The real research is going to be conducted when the teaching practicum is started. The process of creating lesson plan will be done once in a week in the first month, and twice in a week for the following months.

The next step is to observe the learning process when the pre-service teachers act as the actual classroom teachers under the supervision from the in-service teacher. The conformity between the syllabus and the teaching practice will be analy- zed. The aspects which are going to be observed and analyzed further are (1) the use of learning approach, (2) the use of learning method, (3) the use of learning media, and (4) the steps and evaluation technique implemented by the pre-service teachers.

Specifically, data is going to be analyzed deeper by synchronizing the practice with the process of supervision regarding to on how the music materials are constructed by combining the hard skill and soft skill of music. Descriptive qualitative analysis is going to be implemented to process, verify, and summarized the data interactively.

The interview will be conducted in the middle of pre-service teachers' teaching process analysis in order to obtain the information related to the performance of in-service teacher in conducting the supervision. The interviewees will be the vice head master of curriculum and the in-service music teacher. Furthermore, research will be taken place in Pasundan 8 Senior High School Bandung, starts from the midst of February to the midst of May, 2014 during the teaching practicum program. The research instruments will be (1) the guidelines of observation, (2) the guidelines of interview, (3) the documental stu- 
dy of lesson plans, as well as (4) documentation.

\section{RESULTS AND DISCUSSION}

The results of the study have successfully revealed the roles of in-service teacher to prepare the pre-service teachers, as follows:

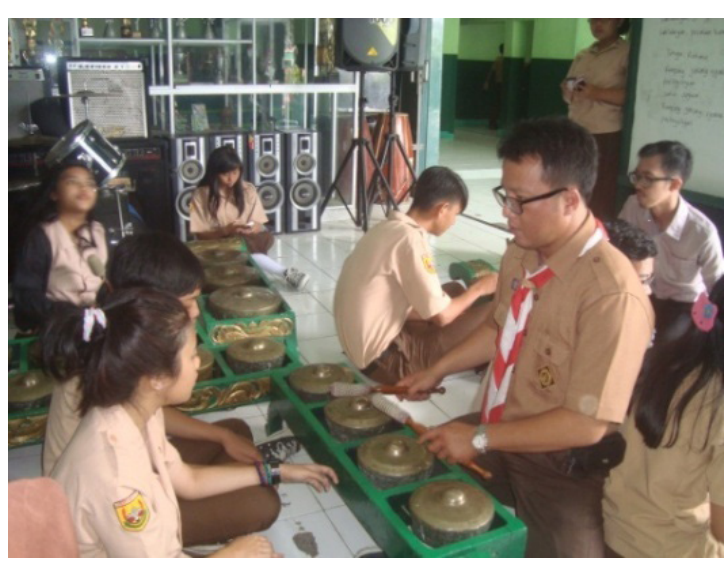

Figure 2. In-Service Teacher Gave an Example to Students (Documentation by Latifah, April $2,2014)$

In applying the learning approach in the classroom, pre-service teachers were following suggestions from the in-service teacher as a result of supervision. Several approaches which had been given by the in-service teacher as the examples were experience learning, cooperative learning, as well as appreciation. As a consequence, approaches which were usually implemented by pre-service teachers were also as the same as what they have learnt from an in-service teacher during supervision. The approaches were experience learning, cooperative learning, as well as appreciation by conducting a group study to discuss new musical events they saw from the audio-visual media. During the supervision, it could be seen that the in-service teacher implemented both experiential learning and cooperative learning approach in teaching Degung rhythmical ensemble. In implementing the approaches, in-service teacher asked students to experience themselves to play Degung (see figure 2).
Supervision related to the learning method was done during the learning process in the classroom. In-service teacher demonstrated the implementation of learning methods in teaching music. Methods which were applied by in-service teachers and were taught to the pre-service teachers were the methods of practice, lecturing, questions and answers, demonstration, and imitation. Lecturing method was implemented while giving an introduction to students related to the learning materials which were going to be given. Questions and answers method was conducted during the learning process when students who had not understood the materials delivered several questions related to the given materials. In addition, this method was also implemented during the time of learning music practice. When students had difficulties in understanding or feeling the rhythm pattern or singing a certain song, they would ask the teacher to find the answers or problem-solving. In this case, service teacher and pre-service teachers would give the answers by demonstrating or showing the way those music instruments or songs were produced or sounded. The method of practice was done during the time when in-service teacher or pre-service teachers taught music. They would always ask the students to play music instruments by experiencing the way the instruments were played, both in rhythmical music ensemble or Degung.

\section{Supervision Related to the Usage of Media in Music Teaching}

The results of the supervision related to the usage of media in music teaching were seen when pre-service teachers performed teaching and learning in the classroom. In teaching, pre-service teachers seemed to always use the learning media. The learning media which were usually used were audio and audio-visual media. Audio media was used to give an understanding to students related to the language of sounds that would be needed by students. This media would also become the tool to understand the concept and practice of 
certain music. In addition to the audio media was the presence of audio-visual media which was used to show the meanings behind the process of playing the music instruments contextually to students. By contextually meant that students were expected to understand and realize how certain sounds of music were sounded and played by the musicians shown in the provided media.

Another media which was always prepared in the learning process was music chart. It was used to introduce the text of certain songs that would be sung by students. However, among those media, the most important one was the music instruments themselves. It would be very important for students who were going to practice to play the music instruments. All of those media were used by the in-service teachers during the learning process. During the time of supervision, the in-service teacher demonstrated the ways to use teaching and learning media which were later imitated by pre-service teachers.

\section{Supervision Related to Evaluation}

Supervision related to evaluation was done by in-service teacher, with the following steps: in the beginning, in-service teacher introduced the technique of evaluation and the evaluation instrument which was used during the implementation of the 2013 curriculum. The evaluation instruments comprise the activity of filling out certain rubrics to evaluate the students' character building (soft skill) and scoring related to understanding the music competencies and practice. After that, in-service teacher showed the example of evaluating students to the pre-service teachers directly during the process of learning. The evaluation was done by ticking the columns of providing a rubric based on the students' characters which were observed as well as by giving score or grade to the students based on their abilities to comprehend the competencies during the process of practicing to play Degung musical instruments. Those evaluation activities were imitated and deve- loped by pre-service teachers during the teaching practicum.

\section{Supervision Related to Aspects of Hard Skill and Soft Skill}

Supervision related to the aspect of hard skill was initiated by the supervision to create the lesson plan. The lesson plan which was created by pre-service teachers was implemented well by them in the classroom. It was proof that supervision related to create and implement lesson plan was done well by both in-service and pre-service teachers. Supervision which was conducted to help pre-service teachers in creating lesson plan was done by giving them an explanation related to the gap between what is written in the lesson plan and the theories of learning that will be implemented in the real context of classroom learning at school. The supervision was continued by giving feedback to pre-service teachers related to the lesson plan. In detail, in-service teacher gave an explanation related to the percentage of time allocation which was done during the learning process as well as the opening, main, and closing activities which would be done by pre-service teachers. Besides giving explanation related to the comprehence of creating lesson plans, in-service teacher also taught the pre-service teachers the steps to teach Degung in a contextual way as it was always done in Pasundan 8 Senior High School Bandung. The process of learning Degung in this school was not done by reading the notation $\mathrm{Da} \mathrm{Mi} \mathrm{Na}$ directly, but more by memorizing (ngabeo) and imitating the teachers' demonstration.

The role of in-service teacher in supervising pre-service teachers were also seen from the way he taught the pre-service teachers about hard skill of teaching music. In-service teacher was a model for the students, and he wanted pre-service teachers to also become a good model for the students. For instance, when an in-service teacher taught his students to value the ethics of playing Degung music instrument, he did not allow his students to step over the Degung instrument. Consistently, 
in-service teacher showed that attitude to students. In addition, if there were violations done by students, in-service teacher would remind the students in front of the pre-service teachers, so that the pre-service teachers would know the way to rebuke the students appropriately. Attitudes which were Modeled by the In-Ser-
vice Teacher

There were several attitudes done by in-service teacher which reflected exemplary attitudes towards pre-service teachers. Some of the attitudes were silih asah, silih asih, and silih asuh. In the process of learning Degung, in-service teacher did not doubt to ask students to help each others. He gave an understanding to the students who had more capabilities in playing Degung to help their friends who had difficulties in playing the instrument. For instance, if there were students who had difficulties in playing Kendang instrument, the in-service teacher would ask the more capable students to teach their friends to play Kendang patiently without having the feeling of arrogance. In addition, when Degung was played together, students would be asked to keep the pattern of the rhythm so that the less able students would not face difficulties in following the rhythm. More capable students were also asked to remind their friends when to play the instruments, for instance, gong which was supposed to be played at the end to close the Degung play. Related to the supervision for pre-service teachers, in-service teacher would always remind the pre-service teachers to give their students' music lesson based on Sundanese culture, who emphasized the importance of attitudes and affective aspect which became the main basis of teaching positive character to students.

According to the interview which was conducted in this study to receive information from the in-service teacher on May 7, 2014, the teacher delivered the importance of Sundanese culture attitudes which comprise ngasah, ngasih, ngasuh. Ngasah meant that in teaching, teachers had to give knowledge and attitudes to stu- dents according to humanitarian norms. Ngasih meant to give and care to students as if they were the teachers' own children. Last-ly, Ngasuh meant to take care of or to guide the students to the maturity of thinking and behaving in a mannered character.

He also delivered that the concept of Karawitan had to be understood by students as $R a$ which meant rasa or feeling and Wit which meant karuhun or ancestors. Therefore, Rawit (Karawitan) means the act of feelings and politeness that was based on values which was inherited from the ancestors. Moreover, there were several other Sundanese philosophical terms which were often used by the in-service teacher to educate the students' character. Besides Silih Asah, Silih Asih and Silih Asuh, another term was Aji Luhung, Aji Komara and Aji Wibawa. Aji Luhung was an attitude which required a person to be skillful but not to be arrogant. Aji Komara meant that people were having high value because they were knowledgeable. The last one was Aji Wibawa meant that people had their dignity from their knowledge. All of those philosophical terms were supposed to be implemented in daily attitudes.

Besides the previous terms, in-service teacher was also introduced students to the conception of Sundanese philosopichal term Wawuh ka Gustina, Wawuh ka Dirina, Wawuh ka Alamna. This philosophical term meant to know their God, to know themselves, and to know their environment. People had to know their God in order to be a religious creature that devoted themselves to their God. People had to know themselves in order to develop their skills based on their own potential abilities, and to know environment in order for them to keep the environment well and wisely.

The last Sundanese philosophical term which was usually implemented by the in-service teacher and was taught to students to build their positive character was Murangga Jati Sunda. It was the meaning of life from the perspective of the Sundanese. That term was given to stu- 
dents though the daily attitude approach. Those were the role of in-service teacher in the aspect of teaching soft skill based on a Sundanese cultural value which was considerably meaningful to pre-service teachers who underwent their teaching practicum program in Pasundan 8 Senior High School Bandung.

\section{CONCLUSION}

One of the functions of in-service teacher supervision is to strengthen the teaching competence of pre-service teachers in order to achieve the balance between hard skill and soft skill. Soft skill was taught by giving noble examples and introducing positive characters based on Sundanese culture by the in-service teacher, whereas hard skill was usually given in line with the implementation of soft skill. Hard skill was given to the students by practicing music. The teaching methods which were implemented here were demonstration and imitation by practicing Degung ensemble. This activity was also completed by teaching students the theory of music using the lecturing method as the introduction.

Supervision was done by the inservice teacher by conducting several activities, such as: an initial introduction of the music classroom environment which was continued by having briefing related to the steps of creating lesson plans. The conformity between lesson plan and learning process was exemplified by an inservice teacher by demonstrating the teaching process of Degung music ensemble, starting from the way in-service teachers implemented the teaching approach, the learning method, the learning media, teaching hard skill and soft skill, until the implementation of evaluation techniques. During the teaching practicum, in-service teacher also helped the pre-service teachers by explaining more about the way to teach music in an actual classroom.

From this study, it is concluded that the role of in-service teacher is significant. The roles are to build and strengthen the competences had by the pre-service teachers in order to be professional teachers.

\section{REFERENCES}

Arnett, S. E. \& Freeburg, B. W. (2008). Family and Consumer Sciences Pre- Service Teachers: Impact of an Early Field Experience. Journal of Family and Consumer Sciences Education, 26(1), 48-56.

Cohen-Sayag, E. (2012). Reflective Writing in Pre-Service Teachers'Teaching: What does it Promote? Australian Journal of Teacher Education, 37(10), 20-36.

Danumihardja. (2001). Paradigma Baru Pendidikan. Jakarta: Paramadina.

Deal, D. \& White C. S. (2006). Voices from the classroom: Literacy Beliefs and practices of two novice Elementary teachers. Journal of Research in Childhood Education, 20(4), 313-329.

Haith, M. P., \& Whittingham, K. A. (1012). The impact of being part of an action learning set for new lecturers: a reflective analysis. Action Learning Research and Practice, 9(2), 111-123.

Hamalik, O. (2005). Evaluasi Kurikulum. Bandung: Remaja Rosdakarya.

Kagan, D. M. (1992). Professional growth among preservice and beginning teachers. Review of Educational Research, 62(2), 129-169.

Kerka, S. (2002). Journal writing as an adult learning tool. Practice Application Brief no. 22 Retrieved from: http://www.cete.org/acve/docgen. asp?tbl=pab\&ID $=112$

Knoblauch, D. \& Hoy, W. (2008) "May be I can teach those Kids" The influence on context factors on student teachers' efficacy beliefs. Teaching and teacher Education, 24(2), 166-179.

Leonarda, H. S. \& Marquard, M. J. (2010). The evidence for the effectiveness of action learning. Action Learning: Research and Practice, 7(2), 121-136.

Marshall, W., \& Regenia C. J. (2007).An Investigation on the Impact of a Guided Reflection. Technique in Service- 
Learning Courses to Prepare Special Educators. Teacher Education and Special Education, 30(4), 276-285.

Mulyasa, E. H. (2011). Manajemen \& kepemimpinan Kepala Sekolah. Jakarta: Bumi Aksara.

Parwoto. (1998). Pedoman Pelaksanaan Program Pengalaman Lapangan (PPL) Program Studi PGLB. Jakarta: Dirjen Dikti Depdikbud.

Psacharopoulos, G. (1985). Returns to Education. A Further International Update And Implications. Journal of $\mathrm{Hu}$ man resources, 20(4), 583-604.

Puspita, S., Dewi, W. A., \& Sumaryati, S. (2013). Kendala-Kendala Pelaksanaan Program Pengalaman Lapangan (PPL) Mahasiswa FKIP UNS Di SMK Negeri 1 Sukoharjo Tahun 2012. Jupe, 2(1), 26-38.

Rahmat, K., Cristiana, D. M., \& Lukman, F. (2013). The Implementation of Sundanese Leadership Values in Education Management: A Study on "DasaPasanta" in School Principal Leadership Based on Sundanese Cultural Values of Leadership. International Journal of Education, 5(4), 110-121.

Russel, A. (2012). The Failures files: Perspective on Failure. Action Learning Research and Practice, 9(2), 201-203.

Sami'an \& Analya, P. (2014). Hubungan antara Peran Guru Pamong dan Minat Mahasiswa Menjadi Guru dengan Prestasi Program Pengalaman Lapangan: Studi Kasus Pada Mahasiswa Pendidikan Akuntansi FKIPUMS. Jurnal Pendidikan Ilmu Sosial, 24(1), 47-53.

Schulz, R. (2005). The practicum: More than practice. Canadian Journal of Education, 28(1/2), 147-169.
Shalaway, L. (2005). Learning to Teach. USA: Corbis.

Slockdale, S. L. \& William, R. L. (2004). Cooperative learning groups at the college level: Differential effects on high, average and low exam performers. Journal of Behavioural Education, 13(1), 37-50.

Soewito, N. (2013). Materi Pembekalan PPL. Yogyakarta: Pusat Pengembangan Praktik Pengalaman Lapangan dan Praktik Kerja Lapangan Universitas Negeri Yogyakarta.

Suryalaga, H. (2009). Kasundaan Rawayan Jati. Bandung: Yayasan Nur Hidayah.

Tim Pengembang Kurikulum. (2013). Dokumen Kurikulum 2013. Jakarta: Kementerian Pendidikan dan Kebudayaan, Desember 2012.

Tuli, F. \& File, G. (2010). Practicum Experience in Teacher Education. Ethiopian Journal of Education and Sciences, 5(1), 108-116.

Widarto, P. \& Noto Widodo. (2012). Pengembangan Model Pembelajaran Soft Skills untuk Siswa Sekolah Menengah Kejuruan. Cakrawala Pendidikan, 31(3), 1-20.

Widiastuti, N. W. \& Suhandana, I. G. A. (2013). Studi Evaluasi Efektivitas Pelaksanaan Praktik Pengalaman Lapangan (PPL) Mahasiswa Fakultas Pendidikan Olahraga dan Kesehatan (FPOK) IKIP PGRI Bali Tahun 2012. Jurnal Penelitian, 4(1), 1-12.

Zaher, A. (2010). Effects of Cooperative Learning vs. Traditional instruction on Prospective Teachers' Learning Experience and Achievement. Journal of Faculty of Educational Science, 43(1), 151-164. 